\title{
THE RISE OF LEADERSHIP FOR LEARNING: CONCEPTUALIZATION AND PRACTICES
}

School leaders often stands in the spotlight due to their roles and responsibilities in school effectiveness (Adams, 2018; Daniëls, Hondeghem, \& Dochy, 2019) and the accountability-driven context they work in (Hitt \& Tucker, 2016; Leithwood, 2010). Principals have a considerable potential in enhancing student-learning outcomes by creating learning environments (Daniëls, Hondeghem, \& Dochy, 2019) and influencing teachers, organisational policy and processes (Hitt \& Tucker, 2016). Consequently, after decades of research, leadership in education resulted in numerous approaches of leadership e.g. situational leadership, transformational leadership, instructional leadership, and distributed leadership (Adams, 2018; Daniëls, Hondeghem, \& Dochy, 2019).

These leadership theories emerged either as an extension of existing theories or a critique on previous theories. Instructional leadership focusses on the improvement of teaching and learning directly influencing student achievement (Grobler, 2013; Hallinger, et al., 2018; Harris, et. al., 2019). Now recognised as an important component of effective schools, instructional leadership is largely a top-down approach it mainly focuses on the principal and their tasks in coordinating and controlling instruction (Aas \& Brandmo, 2016).

The awareness of school context as an important factor in school leadership and school effectiveness has recently risen again (Hallinger, 2011). Situational leadership theories belief that the outcomes of leadership are influenced by context. Teachers should be treated according to the dynamics of the situation and that principals should be aware of opportunities to improve teachers' skills and confidence (Thompson \& Glas $\varnothing, 2015$ ). Then, the concept of transformational leadership arose emphasizing school principals should motivate teachers and students by raising their consciousness about the organisational goals (Sun \& Leithwood, 2012). Transformational leadership aims to foster capacity building and higher levels of teacher commitment to organisational goals, leading to increased effort and productivity (Bass \& Avolio, 1994).

Transformational leadership contrasts with instructional leadership as it is described as a shared leadership model and aims for school improvement and student achievement through bottom-up actions (Aas \& Brandmo, 2016; Sun \& Leithwood, 2012). This led to the development of new leadership models orientated towards collaboration and organisational learning, such as distributed leadership (Hallinger, 2003). Distributed leadership recognises that leadership can be distributed among the school members. It emphasizes interactions rather than actions, and that leadership is not restricted to those with a formal leadership position (Harris \& De Flaminis, 2016). Leithwood, Harris, and Hopkins (2008) state that the influence of distributed leadership on schools and pupils is enhanced when school leadership is widely distributed.

The past 15 years has seen the rise of leadership for learning in school leadership research (Daniëls, Hondeghem, \& Dochy, 2019). Now a global phenomenon after receiving substantial attention from leading scholars (Hallinger \& Huber, 2012), leadership for learning integrates different aspects of previous leadership theories such as situational leadership, transformational leadership, instructional leadership, and distributed leadership culminating in the use multiple theories for school 
leadership. See Figure 1. However, till date there is no solid definition of leadership for learning. Current knowledge views leadership for learning as the process in which the whole school community actively participates in the improvement of learning (Marsh, 2012).

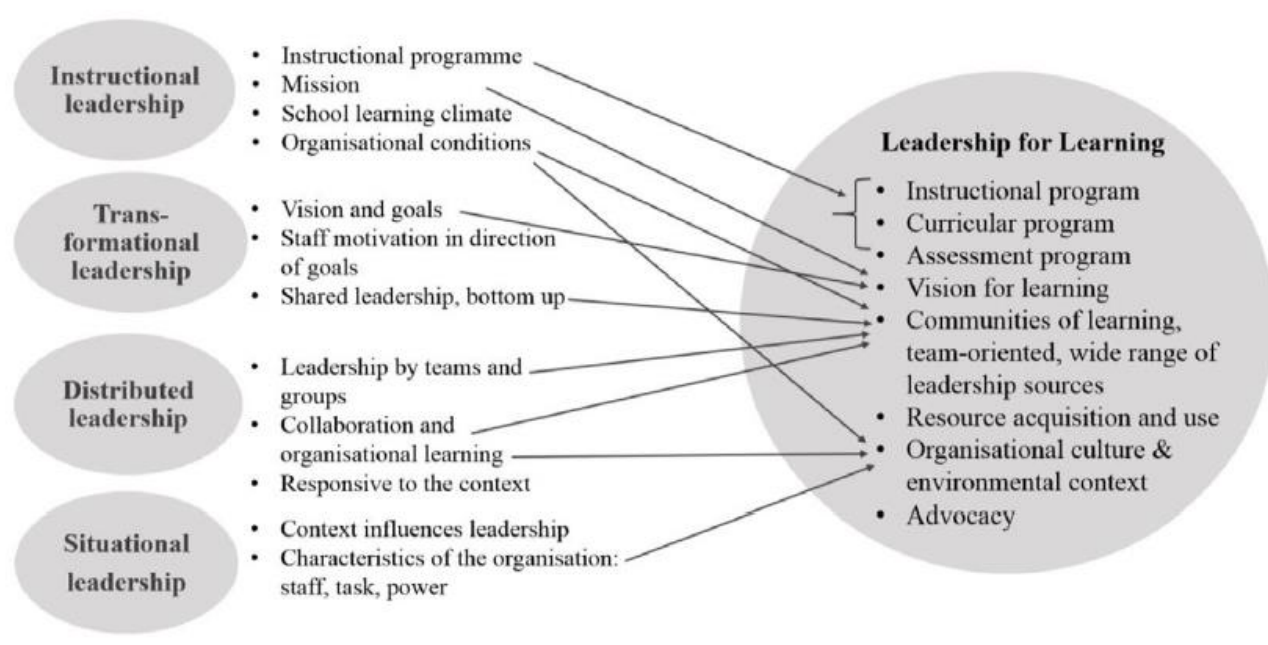

Figure. 1. Relation between Instructional, Transformational, Distributed and Situational Leadership and Leadership for Learning. Sources: Leadership for learning (Daniëls, Hondeghem, \& Dochy, 2019)

Murphy et al. (2007) conception of leadership for learning is to first focus curricula, instruction, learning, and teaching and secondly to enable other school factors such as administration, organisation and finance work smoothly to improve student learning. Murphy et al. further conceptualized leadership for learning integrating features of situational leadership, transformational leadership, instructional leadership, and distributed leadership under eight major dimensions: instructional programme, curricular programme, assessment programme, vision for learning, communities of learning, resource acquisition and use, organisational culture and advocacy. In summary, there is room to further investigate leadership for learning, much to discover about the factors that inhibit its effectiveness, and the approach to effectively address school leadership challenges in the $21^{\text {st }}$ century.

\section{REFERENCES}

Aas, M., \& Brandmo, C. (2016). Revisiting instructional and transformational leadership. Journal of Educational Administration, 54(1), 92-110.

Adams, D. (2018). Mastering Theories of Educational Leadership and Management. Kuala Lumpur: University of Malaya Press.

Bass, B., \& Avolio, B. (1994). Improving organisational effectiveness through transformational leadership. Thousand Oaks, CA: Sage.

Daniëls, E., Hondeghem, A., \& Dochy, F. (2019). A review on leadership and leadership development in educational settings. Educational Research Review.

Hallinger, P., Adams, D., Harris, A., \& Jones, M. (2018). Review of conceptual models and methodologies in research on principal instructional leadership in Malaysia: A case of knowledge construction in a developing society. Journal of Educational Administration, 56(1), 104-126. 
Hallinger, P. (2003). Leading educational change: Reflections on the practice of instructional and transformational leadership. Cambridge Journal of Education, 33(3), 329-352.

Hallinger, P., \& Huber, S. (2012). School leadership that makes a difference: International perspectives. School Effectiveness and School Improvement, 23(4), 359-367.

Harris, A.; Jones, M., Adams, D., Cheah, K. (2019) Instructional Leadership in Malaysia: A Review of the Contemporary Literature, School Leadership \& Management, 39(1), 76-95.

Harris, A., \& De Flaminis, J. (2016). Distributed leadership in practice: Evidence, misconceptions and possibilities. Management in Education, 30(4), 141-146.

Hitt, D., \& Tucker, P. (2016). Systematic review of key leader practices found to influence student achievement: A unified framework. Review of Educational Research, 86(2), 531-569.

Leithwood, K. (2010). School leadership in the context of accountability policies. International Journal of Leadership in Education: Theory and Practice, 4(3), 304326

Leithwood, K., Harris, A., \& Hopkins, D. (2008). Seven strong claims about successful school leadership. School Leadership \& Management, 28(1), 27-42.

Marsh, S. (2012). Improving student learning in schools: Exploring leadership for learning as a community activity. Leading \& Managing, 18(1), 107-121.

Sun, J., \& Leithwood, K. (2012). Transformational school leadership effects on student's achievement. Leadership and Policy in Schools, 11(4), 418-451.

Thompson, G., \& Glaso, L. (2015). Situational leadership theory: A test from three perspectives. The Leadership \& Organization Development Journal, 36(5), 527 544.

Donnie Adams

Editor of International Online Journal of Educational Leadership

Faculty of Education, University of Malaya donnieadams@um.edu.my

and Noni Nadiana Binti Md Yusoff Faculty of Education, University of Malaya 